\title{
MISI MULTIKULTURAL YESUS KEPADA PEREMPUAN KANAAN BERDASARKAN MATIUS 15:21-28
}

\author{
Adi Putra ${ }^{1}$, Yane Henderina Keluanan ${ }^{2}$ \\ Sekolah Tinggi Teologi Pelita Dunia ${ }^{1}$ \\ Sekolah Tinggi Teologi Setia Jakarta ${ }^{2}$ \\ addiepoetra7@gmail.com
}

\begin{abstract}
This research is about Jesus' multicultural mission to Canaanite women based on Matthew 15:21-28. This study examines the nature and principles of the task carried out by Jesus to the Canaanite women. Interestingly, the church often considers Jesus' mission to be exclusively for the Jews. However, this case shows that the mission was opened to non-Jewish nations. By using qualitative research methods, this study obtained several conclusions. First, based on the description of the interpretation of Matthew 15:21-28 and taking into account the context and background of the Canaanite woman, it is clear that Jesus' ministry or mission to Canaanite women is clear is a multicultural mission. Second, in principle, Jesus' ministry to Canaanite women (Matt. 15:21-28) qualifies as a multicultural mission. Because it has fulfilled all theologies that are part of multicultural theology, such as relational, social, operational, moral, and transformational theology. Third, Jesus' ministry to the Canaanite woman (Matt. 15:21-28) fulfills every aspect of the Christocentric dimension in the construction of multicultural theology.
\end{abstract}

Keywords: Multicultural Mission, Canaanite Women, Jesus Mission, Multicultural Theology

\begin{abstract}
Abstrak. Penelitian ini tentang misi multikultural Yesus kepada perempuan Kanaan yang didasarkan pada teks Matius 15:21-28. Penelitian ini mengkaji natur hingga prinsip misi yang dilakukan oleh Yesus kepada perempuan Kanaan. Yang menarik di sini adalah seringkali gereja menganggap misi Yesus hanya diperuntukkan secara eksklusif kepada orang Yahudi. Namun dari kasus ini menunjukkan bahwa misi itu ternyata dibuka kepada bangsa-bangsa non-Yahudi. Dengan menggunakan metode penelitian kualitatif, maka penelitian ini mendapatkan beberapa kesimpulan. Pertama, berdasarkan uraian tafsiran terhadap teks Matius 15:21-28 dan dengan memperhatikan konteks serta latar belakang dari perempuan Kanaan itu, maka terlihat jelas bahwa pelayanan atau misi Yesus kepada perempuan Kanaan merupakan misi multikultural. Kedua, pelayanan Yesus kepada perempuan Kanaan (Mat. 15:21-28) secara prinsip memenuhi syarat dikategorikan sebagai misi multikultural. Oleh karena telah memenuhi semua teologi yang merupakan bagian dari teologi multikultural, seperti: teologi relasional, sosial, operasional, moral dan transformasional. Ketiga, pelayanan Yesus kepada perempuan Kanaan (Mat. 15:21-28) memenuhi setiap aspek dari dimensi kristosentris apabila dikaitkan dengan rancang-bangun teologi multikultural.
\end{abstract}

Kata Kunci: Misi Multikultural, Perempuan Kanaan, Misi Yesus, Teologi Multikultural

Yesus dan pelayanan-Nya adalah model yang ideal bagi setiap orang Kristen untuk membangun prinsip dan bentuk berteologi yang benar dan terimplikasi dalam setiap kehidupan praktisnya (Mau, 2021). Untuk 
mengerti dan memahami seperti apa bentuk dan prinsip pelayanan yang dikerjakan oleh Yesus, maka setiap orang Kristen harus melihatnya dalam catatan Alkitab, khususnya kitab-kitab Injil (Stevanus, 2018).

Ketika menjalankan misi-Nya di dunia dalam kurun waktu 3 tahun, Yesus tidak secara eksklusif hanya menjangkau orang-orang Israel saja. la juga melayani kelompok di luar Israel, seperti perempuan Samaria dan perempuan Kanaan (Siro Fenisia). Bahkan ketika melayani di Galilea, terdapat indikasi yang kuat dalam Injil bahwa pelayanan itu diperuntukkan kepada bangsa-bangsa lain (bdk. Mat. 4:15-16) (Harming, 2017).

Matius menulis pasal 4:15-16 dengan mengutip dari Yesaya 8:239:1 untuk menegaskan bahwa pelayanan Yesus ke Galilea untuk melayani di wilayah bangsa-bangsa lain. Ketika Yesus menetap di wilayah yang disebut sebagai tanah suku Zebulon dan suku Naftali, penduduknya terdiri dari bangsa-bangsa lain (pencampuran antara orang Yahudi dan nonYahudi) (Putra, 2015). Hal ini mengindikasikan betapa pelayanan yang dikerjakan oleh Yesus selama tiga tahun cenderung multikultural atau kepada beragam etnis (bukan hanya kepada orang Israel saja).

Pendapat di atas diperkuat dengan anggapan yang mengatakan bahwa selama tiga tahun menjalankan misi-Nya, Yesus lebih fokus di wilayah Galilea (Utara) daripada wilayah Yerusalem (Selatan). Jacob van Bruggen membenarkannya dengan mengatakan, "Dan Dia tetap di sana selama (paling tidak) hampir dua tahun, dengan hanya mengadakan beberapa kali perjalanan ke Yerusalem untuk menghadiri hari raya di 
sana" (Bruggen, 2001). Dengan demikian, tidaklah keliru apabila mengatakan pelayanan Yesus selama di bumi untuk menjangkau berbagai macam etnis (multikultural).

Fakta di atas seharusnya membuka mata setiap orang Kristen tentang pentingnya membuka sekat yang menghalangi untuk bergaul atau berkomunikasi dengan berbagai macam perbedaan (suku, budaya, bahasa hingga agama) guna dapat membuka peluang untuk "memenangkan" mereka bagi Kristus. Karena sejatinya, Tuhan tidak pernah memisahkan orang Kristen dalam konteks locus dengan orang non-Kristen. Bukan supaya orang Kristen dipengaruhi mereka, melainkan untuk memenangkan mereka.

Seperti yang dikemukakan oleh John Stott bahwa gereja memiliki tanggung jawab ganda dalam kaitannya dengan dunia sekitar. Di satu sisi gereja (orang Kristen) ada untuk hidup, melayani, dan bersaksi di tengahtengah dunia ini. Namun, pada sisi yang lain gereja menghindarkan diri agar tidak terkontaminasi oleh dunia. Jadi gereja tidak menjaga kesuciannya dengan melarikan diri dari dunia (eskapisme) atau pun mengorbankan kekudusannya dengan menjadi serupa (konformisme) dengan dunia (Stott, 2017).

Gereja perlu menyadari kewajibannya untuk bersaksi. Untuk itulah gereja harus memikirkan sebuah konsep misi yang dapat menjangkau berbagai macam etnis karena dunia memiliki banyak etnis yang membutuhkan Injil. Gereja harus bersedia memikirkan sebuah teologi 
yang dapat menolong untuk memiliki sebuah teologi yang kuat secara prinsip Alkitab namun dapat menjangkau multi-etnis. Teologi itu disebut teologi multikultural (Band. Panuntun et al., 2020).

Berdasarkan kesaksian kitab Injil, Yesus merupakan tokoh yang telah menerapkan teologi khususnya yang berkaitan dengan misi. Dalam mengerjakan misi-Nya, Yesus telah menunjukkan teologi multikultural yang diimplementasikan secara praktis dalam misi-Nya. Hal itu terkonfirmasi dengan tegas sejak inkarnasi-Nya (kelahiran) hingga pelayanan-Nya. Salah satu contoh konkretnya adalah pelayanan Yesus kepada Perempuan Kanaan (Mat. 15:21-28) atau Perempuan Siro-Fenisia (Mrk. 7:24-30).

Informasi tentang ungkapan perempuan Kanaan dalam Injil Matius dikomentari oleh Leon Morris dengan mengatakan,

la adalah seorang Kanaan, sebuah ras yang dilacak hingga sekitar 3000 SM. Tirus dan Sidon merupakan pusat perdagangan dan dari sana, orang-orang Kanaan melakukan perjalanan yang lama dan panjang. Ras ini sangat berbudaya. Misalnya, abjad pertama kali diketahui berasal dari orang-orang Kanaan yang bekerja dengan orang Mesir di pertambangan semenanjung Sinai (Morris, 2016).

Perempuan itu jelas merupakan perempuan non-Yahudi. Itu berarti ia berbeda kebudayaan dan agama dengan Yesus, namun Yesus tetap memberikan perhatian kepadanya. Sekalipun kehadiran Yesus di wilayah itu, dituliskan dalam tendensi "menyingkir" namun hal itu tidak mengurangi kuasa dan substansi misi yang dikerjakan oleh Yesus. Bahkan sebaliknya, dari kisah ini dapat menjadi rujukan yang penting bagi setiap orang Kristen 
untuk melakukan misi yang sama dengan Yesus, yakni misi multikultural. Hal ini dibenarkan oleh Grant R. Osborne dengan mengatakan bahwa Yesus telah pergi melintasi wilayah Israel, dan misi ini dilakukan oleh Yesus sebagai persiapan misi yang akan dikerjakan oleh murid-murid-Nya untuk menjangkau bangsa-bangsa lain (Osborne, 2010).

Hal itulah yang akan dijelaskan selanjutnya, bagaimana bentuk dan natur pelayanan yang dilakukan oleh Yesus kepada perempuan Kanaan itu. Supaya dapat menjadi model bagi orang Kristen untuk melakukan misi multikultural sekaligus untuk mengaitkannya dengan teologi multikultural yang merupakan acuan prinsip dari misi kultikultural.

\section{METODE}

Penelitian ini menggunakan metode kualitatif dengan penekanan kepada kajian pustaka. Ada beberapa jenis atau sumber data dalam penelitian kualitatif, seperti kata-kata, tindakan, dan juga dokumen yang dapat menjadi data tambahan. Itulah sebabnya, dalam penelitian kualitatif jenis datanya dibagi ke dalam kata-kata dan tindakan, sumber data tertulis, foto dan statistik (Moleong, 2010). Pada penelitian ini lebih menitikberatkan kepada sumber data tertulis, khususnya literatur-literatur yang dikaji, dianalisis, disintesiskan, untuk menghasilkan sebuah teori atau data kualitatif khususnya untuk misi multikultural. 


\section{HASIL}

\section{Misi Multikultural Yesus dalam Matius 15:21-28}

Berdasarkan uraian tafsiran terhadap Matius 15:21-28 maka di sana dijumpai beberapa poin yang menegaskan bahwa misi ini dapat dikategorikan sebagai misi multikultural.

\section{Misi yang Multi-Etnis}

Sekalipun perempuan itu bukanlah orang Yahudi, namun Yesus tetap menyembuhkan anak perempuannya dari kerasukan setan. Bahkan pada bagian terakhir ayat tersebut memberikan sebuah penegasan bahwa perempuan itu memiliki iman yang luar biasa. Hal inilah yang membuat Yesus akhirnya menyatakan mujizat-Nya untuk menyembuhkan anak perempuannya.

Berdasarkan apa yang dilakukan oleh Yesus dalam perikop ini harusnya dapat membuat gereja menjalankan misi yang sama, yakni misi yang dialamatkan kepada multi-etnis. Oleh karena Yesus pun telah menugaskan gereja-Nya untuk pergi menjadikan semua bangsa murid Kristus. Sills mengatakan, Yesus mengingatkan kerumunan orang itu bahwa dalam Amanat Agung, gereja diutus ke panta ta ethne (semua suku bangsa) dan bahwa ini maksudnya setiap kelompok suku (Sills, 2011). Artinya gereja harus menjalankan misi kepada multi-etnis, seperti yang telah dimandatkan oleh Yesus dalam Amanat Agung bahkan juga telah dicontohkan dalam misi yang dikerjakan oleh-Nya selama melayani. 


\section{Misi yang Multi-Culture}

Misi yang dilakukan oleh Yesus kepada perempuan Kanaan memperlihatkan misi multi-culture atau misi kepada orang yang berbeda suku. Memang inilah yang menjadi tema sentral dari misi multikultural. Oleh Yesus sekalipun diutus hanya kepada orang-orang Yahudi yang terhilang, namun dalam konteks ini sepertinya ada pengecualian. Sebab perempuan itu jelas adalah perempuan Kanaan. Namun Yesus pada akhirnya menyembuhkan anak perempuannya dari kerasukan setan.

Menurut Kevin J. Vanhoozer, kebudayaan adalah sistem yang diekspresikan dalam bentuk-bentuk objektif, hal-hal yang diterima oleh suatu masyarakat sebagai nilai-nilai yang mengarahkan dan menopang kebebasan manusia (Vanhoozer, 2002). David J. Hesselgrave mengemukakan permasalahan yang seringkali dihadapi oleh misionarismisionaris yang diutus masuk ke suku-suku tertentu yang memiliki kebudayaan berbeda (Hesselgrave, 2005).

Sebenarnya Yesus pun diperhadapkan dengan jalan buntu budaya ketika hendak menyatakan kuasa dan kasih Allah kepada perempuan Kanaan. Itulah sebabnya, ketika perempuan itu pertama kali berseru dan meminta tolong kepada-Nya, Yesus malah berdiam diri dan tidak meresponsnya. Bahkan ketika Yesus merespons, Yesus justru mengeluarkan kata-kata yang menyiratkan adanya gap yang besar di antara mereka yang bisa saja membatalkan terjadinya misi multikultural. 
Lalu, apakah yang memungkinkan Yesus akhirnya dapat menyembuhkan anak perempuan dari perempuan Kanaan itu? Sebenarnya ada dua faktor utama. Pertama, belas kasihan Yesus, dan kedua, iman perempuan Kanaan itu. Sekalipun dalam perikop ini, tidak dijelaskan secara eksplisit, namun secara tabiat Yesus adalah pribadi yang selalu berbelas kasihan (bdk. Luk. 7:11-15; Mrk. 6:34; 1:41, dll.). Sehingga dalam konteks ini, dapat dipastikan bahwa Yesus pun berbelas kasihan kepada perempuan itu. Kemudian faktor kedua, di mana perempuan itu memiliki iman yang besar, bahkan pujian itu juga keluar dari mulut Yesus. Faktor ini menjadi faktor yang mengikuti faktor pertama, sehingga keduanya menjadi tak terpisahkan untuk menilai misi multikultural yang dilakukan Yesus kepada perempuan Kanaan.

\section{Misi yang Multi-Religi}

Yesus bermisi kepada perempuan Kanaan atau yang seringkali disebut sebagai perempuan kafir. Orang Israel biasanya menyebut atau mencap bangsa-bangsa di luar Israel sebagai "orang kafir" atau "bangsa kafir". Oleh karena mereka berasal dari bangsa-bangsa non-Yahudi, maka berarti mereka pun berbeda agama dengan orang Yahudi. Sehingga dalam konteks Yesus dan perempuan Kanaan, maka dapat dikategorikan sebagai misi yang multi-religi. Misi multi-religi memiliki prinsip yang sama dengan misi multi-etnis dan multi-culture. Oleh karena seringkali terjadi bahwa orang yang berbeda suku dan budaya maka dapat juga berbeda agama. 
Yang menarik dalam konteks Yesus melayani perempuan Kanaan adalah pengenalan tentang Yesus yang dimiliki oleh perempuan itu tentang siapa Yesus. Selain itu juga tentang kepercayaannya (iman) yang luar biasa. Karena sekalipun dia tidak beragama Yahudi namun dia memiliki pengetahuan tentang Yesus adalah Mesias atau Anak Daud.

Hal inilah yang harusnya menjadikan gereja masa kini begitu memperhatikan dan memprioritaskan pelayanan multikultur dalam konteks multi-religi. Bahkan ini juga terakomodir dalam prinsip dan spirit misi yang tertuang dalam Amanat Agung Yesus (Mat. 28:18-20). Oleh karena berbicara misi kepada semua etnis maka tidak menutup kemungkinan akan bersinggungan dengan semua agama.

Konteks misi multikultural dalam relasinya dengan agama-agama lain jauh melampaui dengan dialog antar-umat beragama yang ditawarkan oleh Paul F. Knitter. Karena bagi Knitter penting sekali orang Kristen untuk menghentikan perdebatan teologis, dan mulai membangun dialog dan persahabatan dengan agama-agama yang lain. Dialog ini disebut sebagai dialog etikal yang bertanggung jawab secara global dan memampukan orang Kristen membentuk berbagai persahabatan baru dengan umat beragama yang lain, persahabatan yang diukir dan dipererat dalam pengalaman yang dibagikan dalam tindakan nyata penuh kasih bagi kesejahteraan bersama (Knitter, 2008). Yesus tidak hanya bertindak untuk menolong perempuan Kanaan itu, tetapi juga bersaksi dan memenangkan 
perempuan itu serta mengalami sebuah pengenalan akan Tuhan yang sejati.

Misi yang Menghadirkan Unsur Kemanusiaan dan Keilahian

Misi yang dikerjakan oleh Yesus kepada perempuan Kanaan, selain bersifat multi-etnis, multi-culture, dan multi-religi; hal yang tidak kalah penting dari itu adalah misi itu menghadirkan unsur kemanusiaan dan keilahian. Apabila melakukan misi hanya menghadirkan unsur kemanusiaan saja, maka cenderung misi yang dikerjakan hanya sebatas pelayanan sosial. Di mana penginjilan jenis ini banyak dipraktikkan oleh gereja pada masa kini, terutama dari kalangan gereja-gereja yang telah terkontaminasi oleh pemahaman teologi liberal, atau biasa disebut gereja arus utama. Seperti yang dikemukakan oleh Hengky Wijaya bahwa pandangan modern (kalangan liberal) misi mencakup penginjilan dan pelayanan sosial, namun bagi mereka penginjilan tidak lebih penting daripada pelayanan sosial (Wijaya, 2017).

Henk Venema mengutip pendapat Thomas Aquinas yang membedakan dua jenis pekabaran Injil (misi) yang dilakukan oleh gereja. Pertama, ditujukan kepada kaum Yahudi dan orang Kristen yang tersesat. Kedua, kepada agama lain, seperti: orang Islam dan orang Kafir (Venema, 1997). Itulah sebabnya, misi multikultural tidak akan cukup apabila hanya menghadirkan unsur kemanusiaan saja, karena justru mereka memerlukan kehadiran Tuhan dan Kristus untuk mengubah dan mentransformasi hidup mereka. Hal inilah yang telah dilakukan oleh 
Yesus pada pelayanan-Nya kepada perempuan Kanaan. Yesus tidak menghilangkan nuansa pluralitasnya namun tetap memegang dan mengutamakan substansi misi yang dikerjakan-Nya, yakni memberitakan kebenaran Kerajaan Surga melalui tindakan, mujizat dan pengajaran-Nya.

\section{PEMBAHASAN}

\section{Pelayanan Yesus kepada Perempuan Kanaan}

Apabila memperhatikan alur narasi dan kalimat pada setiap ayat yang terdapat dalam perikop ini, maka dapat dipastikan bahwa perikop ini dapat dibagi ke dalam tiga poin utama.

Bagian pertama difokuskan kepada ayat 21-22. Kedua ayat ini dideskripsikan perihal penyingkiran Yesus ke wilayah Tirus dan Sidon. Akan tetapi kehadiran Yesus dan murid-murid-Nya di wilayah Tirus dan Sidon ternyata tidak dapat disembunyikan. Oleh karena seorang perempuan mengetahuinya dan akhirnya meminta pertolongan kepada Yesus karena anak perempuannya sedang kerasukan setan dan dikatakan bahwa anak itu sangat menderita. Anizah Chelsia dkk mengatakan, perempuan ini meminta belaskasihan kepada Yesus untuk kesembuhan anaknya. Dapat dilihat bahwa perempuan ini dengan kesungguhan hatinya meminta belaskasihan kepada Yesus agar anaknya dapat sembuh dari kerasukan setan (Chelsia \& Panggarra, 2020).

Craig L. Blomberg mengomentari bagian ini dengan mengatakan, ungkapan "kasihanilah" menggemakan seruan orang-orang buta dalam 9:27 dan memohon kepada Yesus untuk meringankan penderitaan putri 
wanita ini (Blomberg, 1992). Menunjukkan betapa urgen dan mendesaknya kebutuhan tersebut untuk mendapatkan pertolongan.

Morris justru memberikan sebuah argumentasi yang menarik untuk bagian ini. Baginya, ketika perempuan Kanaan itu berkata, "Kasihanilah $a k u$ ", maka sebenarnya perempuan itu tidak sedang mengklaim hak atau jasa, tetapi mencari karunia yang dia tahu tidak layak untuk diterimanya. Sekalipun demikian, ternyata perempuan itu mengenal keagungan Yesus. Karena perempuan itu memanggil Yesus dengan sebutan Tuhan dan kemudian melanjutkan dengan memanggil Yesus sebagai Anak Daud (Morris, 2016).

Perempuan itu menyebut gelar "Tuhan" kepada Yesus (dalam bahasa Yunani: kurios) tidak dimaksudkan sebagai gelar ilahi, namun merupakan sebuah gelar yang penuh penghormatan (Heer, 2003). Pendapat ini masih bisa diperdebatkan terutama karena ungkapan Kurios yang dikemukakan oleh perempuan itu disandingkan dengan gelar Anak Daud. Menurut Blomberg, "Istilah "Anak Daud" (lih. 1:1; 9:27; 12:23) adalah khas Yahudi untuk Mesias dan terbukti sama mencoloknya ketika diucapkan wanita kafir ini” (Blomberg, 1992). Itulah sebabnya sebutan kurie kepada Yesus dalam konteks ini tidak boleh dipahami sekadar sebagai salam yang sopan (seperti: Tuan). Oleh karena dalam konteks ini, kata kurie mempunyai makna atau arti yang lebih dari itu.

Gelar Anak Daud sendiri menunjuk kepada keturunan Raja Daud yang agung dan yang dengan berjalannya waktu digunakan untuk 
menyebut sang Mesias, yang dilihat sebagai pejuang agung seperti layaknya Daud, seorang yang menegakkan sebuah negara yang besar (Morris, 2016). Justru dengan kehadiran ungkapan Anak Daud ini dan disandingkan dengan ungkapan Kurie, maka membuat arti kurie harus dipahami dalam pengertian yang ilahi.

Sepertinya perempuan itu mengemukakan ungkapan tersebut karena memang telah memiliki iman dan dia telah menerima Yesus sebagai Mesias baginya. Sehingga Yesus pergi ke wilayah itu untuk mengkonfirmasi iman dari perempuan Kanaan itu. Karena sekalipun dia bukan orang Yahudi namun ternyata dia telah mengenal Yesus sebagai Tuhan dan Mesias. Artinya, perempuan itu telah memperoleh kasih karunia untuk mengenal Yesus. Atas dasar iman itulah dia datang dan berseru kepada Yesus meminta pertolongan, karena anak perempuannya sangat menderita akibat dari setan yang merasukinya.

Tendensi yang sama juga dijumpai ketika Yesus menyingkir ke wilayah Galilea untuk memulai misi-Nya di sana seperti yang dijelaskan

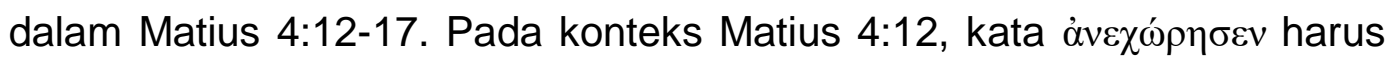
dipahami berangkat dari sebuah tempat ke tempat yang lain untuk menarik diri atau semacam berlindung. Kondisi dan situasi ini yang sama seperti dalam Matius $2: 14 ; 2: 22 ; 15: 21 ; 12: 15 ; 14: 13$, dll. Berdasarkan pengertian itu maka sulit untuk menyepelehkan faktor yang mengatakan bahwa kepergian Yesus ke Galilea juga untuk melindungi diri-Nya. Oleh karena Dia telah mendengar bahwa Yohanes telah ditangkap - sehingga 
berdasarkan peristiwa itu Dia menarik diri dan memutuskan untuk menyingkir ke Galilea (Putra, 2014). Sekalipun demikian, ternyata pelayanan Yesus di sana memiliki dampak yang signifikan karena dari pelayanan itu menghasilkan banyak pengikut Yesus - bahkan murid-murid Yesus mayoritas dari sana. Hal yang serupa juga dapat dilihat dalam konteks pelayanan kepada perempuan Kanaan.

Kemudian beratnya penderitaan anaknya digambarkan dari

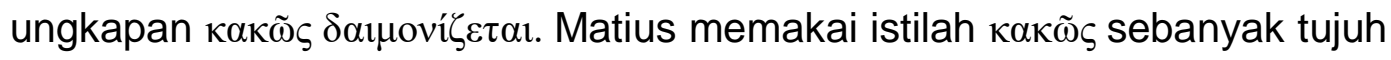
kali dan merupakan yang terbanyak dari semua kitab PB. Kata ini bisa diartikan 'dengan kejam dirasuk setan' atau 'didera oleh setan'. Intinya, di sini ada pemikiran tentang yang jahat, yang sejalan dengan aktivitas setan, bandingkan dengan terjemahan LAI, 'kerasukan setan dan sangat menderita' (Morris, 2016). Intinya perempuan Kanaan itu dengan gamblang mengemukakan betapa anak perempuannya sangat menderita.

Hal itu sekali lagi hendak menegaskan bahwa kepergian Yesus ke wilayah itu merupakan sesuatu yang sangat mendesak dan harus dilakukan karena di sana Yesus akan melepaskan seorang anak perempuan dari belenggu kuasa setan. Sehingga ada dua hal yang urgen tentang kepergian Yesus ke Tirus dan Sidon, yakni: untuk mengkonfirmasi iman dari perempuan Kanaan melalui sebuah pengakuan Yesus adalah Tuhan dan Anak Daud, dan juga untuk melepaskan anak perempuan Kanaan itu dari belenggu kuasa setan. 
Bagian kedua adalah narasi yang cukup panjang karena meliputi ayat 23-26. Pada ayat 23 dikemukakan bahwa Yesus sama sekali tidak menjawabnya. Hal yang tampak kontras diperlihatkan oleh murid-murid, karena dalam ayat yang sama dikemukakan bahwa para murid berkata kepada Yesus, supaya menyuruh perempuan itu pergi karena terganggu dengan teriakan perempuan tersebut.

Yesus sama sekali tidak menjawab atau menanggapi perempuan itu, menjadi sesuatu yang sebenarnya tidak lazim. Oleh karena biasanya Yesus selalu merespons setiap permohonan yang disampaikan kepadaNya dan justru seringkali berinisiatif sendiri untuk menolong sebelum orang tersebut meminta tolong. Namun di sini dikatakan, Dia sama sekali tidak menjawab sekalipun tidak dikemukakan dengan rinci mengapa Yesus bersikap seperti ini. Morris berpandangan, para murid Yesus tampaknya sudah memahami alasannya, perempuan Kanaan ini bukan orang Yahudi sehingga tangisan permohonan minta tolongnya bukan hanya sekadar gangguan. Itulah sebabnya mereka meminta Yesus untuk mengusir perempuan itu. Kata yang digunakan untuk berteriak-teriak sama dengan berseru pada ayat 22, tetapi kali ini para murid berpikir mereka pun menjadi sasaran teriakan karena perempuan itu tidak hanya berteriak kepada Yesus tetapi juga kepada mereka (Morris, 2016).

Sepertinya, sikap diamnya Yesus dan tidak memberikan respons atas permohonan perempuan itu bukan karena merasa tidak nyaman melainkan ada alasan yang lain. Justru yang merasa terganggu dalam 
konteks ini adalah murid-murid-Nya, sehingga mereka berusaha membujuk Yesus supaya mengusir perempuan itu. Heer memberikan alasan yang lebih masuk akal dengan mengatakan bahwa sikap diam Yesus karena dia yakin bahwa Dia sendiri belum terpanggil untuk bekerja di antara pelayanan orang kafir, dan Dia mau sepenuhnya taat kepada Bapa-Nya (Heer, 2003). Alasan ini didukung oleh ungkapan Yesus dalam ayat 24 .

Untuk pernyataan Yesus dalam ayat ini, Blomberg mengatakan, 'Ayat ini secara unik Matius dan sangat paralel dengan 10:6. Mungkin solusi yang sama untuk ketegangan partikularis-universalis berlaku di sini; Yesus pertama-tama harus pergi kepada orang-orang Yahudi, dan kemudian Dia akan beralih ke orang-orang bukan Yahudi (lih. penggunaan 'pertama' dalam Markus 7:27). Akan tetapi, lebih relevan dengan konteks langsung, karena Yesus sebenarnya telah meninggalkan Israel, dalam interpretasi yang menggunakan kata-kata ini sebagai suatu ujian atau dorongan yang dirancang untuk menarik wanita itu ke dalam diskusi lebih lanjut. Mungkin Yesus menjawab sesuai dengan pemahaman stereotip Yahudi tentang 'Anak Daud' (ay. 22) untuk melihat keyakinan macam apa yang dimiliki wanita ini' (Blomberg, 1992).

Ternyata ujian yang diberikan oleh Yesus pada ayat sebelumnya direspons dengan tepat oleh perempuan itu. Perempuan itu bukannya pergi meninggalkan Yesus, tapi malah semakin mendekat bahkan menyembah Yesus sambil berkata kepada-Nya, Tuhan, tolonglah aku (ay. 
25). Osborne memberikan komentarnya untuk ayat dengan berkata

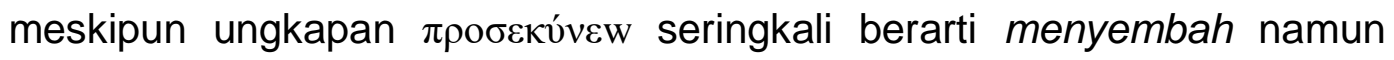
dalam konteks ini lebih menekankan sikap tunduk dan memohon dari perempuan itu. Artinya, perempuan itu sekali lagi memohon kepada Yesus sebagai 'Tuhan' atas penyakit (ay.22) dan memohon padanya untuk menyembuhkan anak perempuannya (Osborne, 2005). Pada ayat ini terlihat jelas kesungguhan perempuan Kanaan itu terhadap pertolongan Yesus kepada anak perempuannya. Itulah sebabnya, perempuan itu mendekat dan berlutut di hadapan Yesus.

Sekalipun demikian, dalam ayat 26 Yesus masih memberikan ujian kepada perempuan itu. Ada yang mengatakan bahwa Yesus telah bersikap kasar kepada perempuan itu karena telah mengidentikkannya dengan "anjing". Namun, apakah benar demikian? Yesus menggunakan analogi sebuah keluarga dan berkata bahwa roti yang disediakan untuk anak harus diberikan kepada anak, bukan untuk anjing. Kata mengambil dalam ayat ini berarti merampas. Sehingga tendensinya adalah menunjukkan ketidakadilan apabila seorang anak dirampas makanannya. Oleh karena dalam keluarga, anak dapat disebut sebagai anggota yang cukup lemah, itulah sebabnya mereka masih harus bergantung kepada orang dewasa dan orang dewasa bertanggung jawab untuk memenuhi kebutuhannya (Morris, 2016).

Kemudian kata "anjing" (кvvapíon) yang banyak menimbulkan perdebatan. Menurut Osborne, khususnya apakah kekuatan dari $\imath-$ kecil 
membuat anjing kecil ini, mungkin sebagai hewan peliharaan rumah tangga. Masalahnya adalah bahwa diminutif telah kehilangan kekuatannya pada abad pertama, jadi ini berbeda untuk dibuktikan; tapi kecil di ikan kecil dalam 15:34b tidak mempertahankan kekuatannya, jadi setidaknya mungkin di sini. Kemungkinan besar Yesus menggunakan istilah itu dalam pengertian Yahudi, karena ini cocok dengan penolakannya untuk memasukkan orang-orang bukan Yahudi dalam misinya, sementara wanita Kanaan mengubah metafora dalam ayat berikutnya (Osborne, 2005). Identik dengan pernyataan Osborne di atas, Morris kemudian mengemukakan, anjing di sini adalah hewan peliharaan; mereka harus diberikan makan, tetapi tidak boleh dengan cara mengorbankan anakanak (Morris, 2016).

Apakah ini merupakan sebuah penghinaan bagi perempuan itu dan juga bangsanya? F.V. Filson mengatakan, tidak sama halnya apabila seseorang mengucapkan kata 'anjing' dengan memakai suara dan air muka yang menghina, dan apabila seseorang mengucapkan kata itu dengan tenang dan manis. Yesus hanya ingin menerangkan kepada wanita itu bahwa pekerjaan-Nya untuk sementara bertujuan bagi kebaikan orang Israel saja (Heer, 2003).

Dengan demikian ungkapan Yesus yang menyebut perempuan itu sebagai anjing tidak bisa dipahami secara harfiah melainkan itu merupakan sebuah ungkapan untuk menyatakan bahwa tujuan utama kedatangan-Nya pertama-tama untuk menyelamatkan orang Israel, seperti 
yang telah dikemukakan pada ayat sebelumnya. Sehingga dengan jelas dilihat bahwa dalam ayat ini tidak ada sama sekali unsur penghinaan atau merendahkan derajat dan martabat perempuan Kanaan itu.

Akan tetapi ungkapan itu sekali lagi tidak membuat perempuan itu putus asa dan menyerah. Hal yang sebaliknya justru dilakukannya dalam ayat 27, di mana dengan gamblang dan tegas dia merespons Yesus, Benar Tuhan, namun anjing itu makan remah-remah yang jatuh dari meja tuannya. Menurut Morris, jawaban perempuan ini menunjukkan bahwa dia tidak mengandalkan posisinya. Oleh karena dia sadar bahwa dia bukan orang Israel dan karena itu tidak bisa baginya untuk mengklaim menjadi bagian umat pilihan. Sekalipun remahan akan tetap ada (Morris, 2016).

Perempuan itu menyadari betapa dia sangat membutuhkan kuasa Yesus untuk menyembuhkan sakit anaknya. Sehingga sekalipun itu sifatnya 'remah-remah' namun itu tetaplah kuasa dari sang Ilahi, Anak Daud. Sehingga baginya, remah-remah sekalipun bukanlah masalah baginya.

Akhirnya Yesus merasa bahwa ujian bagi perempuan itu sudah cukup, karena dia telah menunjukkan sebuah iman dan keyakinan yang luar biasa bahkan melampaui iman yang ada di tanah Israel. Hal itu terlihat dari respons yang diberikan oleh Yesus dalam ayat 28. Heer mengatakan, Yesus heran atas kepercayaan perempuan itu, yaitu kepercayaan yang besar dan dapat mengatasi rintangan-rintangan; la menyadari bahwa la boleh membuat suatu pengecualian, lalu 
menyembuhkan anak dari perempuan itu, walaupun anak itu tidak hadir (penyembuhan jarak jauh) (Heer, 2003).

Memang yang menarik karena dalam perikop ini, Yesus tidak memuji ketekunan atau kerendahan hati perempuan itu; karena imannyalah yang mendasari itu semua. la percaya kepada Yesus dan pada akhirnya, permintaannya dikabulkan oleh Yesus. Dalam ayat ini Yesus berkata, Jadilah kepadamu seperti yang kau kehendaki. Permintaan perempuan itu ternyata dikabulkan. Matius mencatat anak perempuan itu sembuh seketika. Ada dua hal yang penting di sini, yaitu: iman dari perempuan Kanaan ini dan segera sembuhnya penyakit dari si anak perempuan itu. Seperti halnya perwira non-Yahudi yang hambanya sakit, di sini kita menemukan mujizat penyembuhan yang diminta orang lain, penyembuhan dari jarak jauh, dan pujian atas iman yang dimiliki oleh orang non-Yahudi.

\section{KESIMPULAN}

Berikut ini akan diuraikan beberapa kesimpulan dari Misi Multikultural Yesus kepada Perempuan Kanaan Berdasarkan Matius 15:21-28. Pertama, berdasarkan uraian tafsiran terhadap teks Matius 15:21-28 dan dengan memperhatikan konteks serta latar belakang dari perempuan Kanaan itu, maka terlihat jelas bahwa pelayanan atau misi Yesus kepada perempuan Kanaan merupakan misi multikultural. Oleh karena ditujukan kepada bangsa-bangsa lain, tepatnya perempuan 
Kanaan. Itulah sebabnya, misi Yesus kepada perempuan Kanaan dikategorikan sebagai misi yang multietnis, multikultur, dan multireligi.

Kedua, pelayanan Yesus kepada perempuan Kanaan (Mat. 15:2128) secara prinsip memenuhi syarat dikategorikan sebagai misi multikultural. Oleh karena telah memenuhi semua teologi yang merupakan bagian dari teologi multikultural, seperti: teologi relasional, sosial, operasional, moral dan transformasional.

Ketiga, pelayanan Yesus kepada perempuan Kanaan (Mat. 15:2128) memenuhi setiap aspek dari dimensi kristosentris apabila dikaitkan dengan rancang-bangun teologi multikultural. Oleh karena pelayanan Yesus kepada perempuan Kanaan telah mencakup aspek inkarnasi, universalitas soteriologi, teokrasi presentis, universalitas karya Roh Kudus, naturalitas gereja dan terakhir multikulturalitas kekekalan.

\section{DAFTAR PUSTAKA}

Blomberg, C. L. (1992). The New American Commentary: Matthew. Broadman Press.

Bruggen, J. van. (2001). Kristus di Bumi. BPK Gunung Mulia.

Chelsia, A., \& Panggarra, R. (2020). Iman Perempuan Kanaan Berdasarkan Kitab Matius 15: 21-28. Jurnal IImu Teologi dan Pendidikan Agama Kristen, 1(2), 123-143. https://doi.org/10.25278/jitpk.v1i2.511

Harming, H. (2017). Metode Penginjilan Yesus Dalam Injil Yohanes 4:142. Evangelikal: Jurnal Teologi Injili dan Pembinaan Warga Jemaat, 1(2), 162-169. https://doi.org/10.46445/EJTI.V112.73

Heer, J. J. de. (2003). Tafsiran Alkitab Injil Matius. BPK Gunung Mulia.

Hesselgrave, D. J. (2005). Communicating Christ Cross-Culturally (Kedua). SAAT.

Knitter, P. F. (2008). Pengantar Teologi Agama-agama. Kanisius. 
Mau, M. L. (2021). Implementasi Pola Pelayanan Yesus Sebagai Pelayan Menurut Injil Matius 4:23. Phronesis: Jurnal Teologi dan Misi, 4(1), 73-87. https://doi.org/10.47457/PHR.V4I1.127

Moleong, L. J. (2010). Metodologi Penelitian Kualitatif (Revisi). PT Remaja Rosdakarya.

Morris, L. (2016). Tafsiran Injil Matius. Momentum.

Osborne, G. R. (2005). Exegetical Commentary On The New Testament: Matthew. Zondervan.

Osborne, G. R. (2010). Exegetical Commentary on the New Testament: Matthew (C. E. Arnold (ed.)). Zondervan Publishing House, Grand Rapids.

Panuntun, D. F., Pute, J. P., \& Mangalik, L. A. (2020). Model Dialog Imajiner Entas-Entas Untuk Mengkomunikasikan Kristus Kepada Masyarakat Tengger. Visio Dei: Jurnal Teologi Kristen, 2(1), 84-104. https://doi.org/10.35909/visiodei.v2i1.62

Putra, A. (2014). Misi Yesus Ke Galilea Berdasarkan Studi Eksegesis Matius 4: 12-17. Sekolah Tinggi Teologi Injili Arastamar (SETIA) Jakarta.

Putra, A. (2015). Misi Yesus kepada Bangsa-bangsa Lain: Kajian Biblika Terhadap Pelayanan Yesus di Galilea berdasarkan Matius 4:12-17. Penerbit Vieka Wahana Semesta (Views).

Sills, M. D. (2011). Panggilan Misi: Menemukan Tempat Anda dalam Rancangan Allah bagi Dunia ini. Momentum.

Stevanus, K. (2018). Mengimplementasikan Pelayanan Yesus Dalam Konteks Misi Masa Kini Menurut Injil Sinoptik. Fidei: Jurnal Teologi Sistematika dan Praktika, 1(2), 284-298. https://doi.org/10.34081/FIDEI.V1I2.21

Stott, J. (2017). The Radical Disciple: Delapan Aspek Utama dari Pemuridan Kristen yang Sejati. Literatur Perkantas Jawa Timur.

Vanhoozer, K. J. (2002). Dunia dipentaskan dengan Baik? Teologi, Kebudayaan, dan Hermeneutika. In Allah dan Kebudayaan (1 ed.). Momentum.

Venema, H. (1997). Injil Untuk Semua Orang: Pembimbing Ke dalam IImu Missiologi. Yayasan Komunikasi Bina Kasih (YKBK) / OMF.

Wijaya, H. (2017). Misi Dan Pelayanan Sosial: Manakah yang lebih Penting? In Repository STT Jaffray. Sekolah Tinggi Theologia Jaffray. 